\title{
OKOLJSKA GLOBALIZACIJA, SVETOVNO GOSPODARSTVO IN SLOVENIJA
}

\author{
dr. Dušan Plut \\ Oddelek za geografijo, Filozofska fakulteta Univerze v Ljubljani, \\ Aškerčeva 2, SI-I000 Ljubljana \\ e-mail: dusan_plut@t-2.net
}

Izvirni znanstveni članek

COBISS 1.01

\section{Izvleček}

Globalna razsežnost okoljskih problemov je v veliki meri posledica visoko entropijskega modela svetovnega gospodarstva, ki ustvarja prihodke tudi na račun prekomernih pritiskov na okolje. Kot razvojna alternativa se kaže model trajnostno sonaravnega razvoja, ki svetovno gospodarstvo obravnava (zgolj) kot eno od sestavin planetarnega ekosistema. Tudi slovensko gospodarstvo, ki prekomerno troši surovine in energijo, se bo moralo prilagaditi omejitvam okolja.

Ključne besede: geografski koncepti, prostor, pokrajina, kraj

\section{ENVIRONMENTAL GLOBALIZATION, WORLD ECONOMY AND SLOVENIA}

\begin{abstract}
The global extension of environmental problems is, to a high degree, a consequence of a highly entropic model of the world economy which is making income also on account of excessive pressure on environment. A model of sustainable development appears to be a globally acceptable developmental alternative, treating the world economy as merely one of the planetary ecosystem components. The Slovene economy will also have to adjust to the limits of the environment since it is excessively wasting raw materials.
\end{abstract}

Key words: environmental globalization, world economy, sustainable development, Slovenia 


\section{UVOD}

Zgodovinska primerjava razmerja med okoljem in gospodarstvom $\mathrm{v}$ večini primerov ne kaže harmonije, kar zlasti velja za obdobje po industrijski revoluciji. Linearni gospodarski razvoj, zasnovan na predpostavki možnosti trajne količinske gospodarske rasti in povečevanja dobička, je v celotni zgodovini človeštva povzročal okoljske poškodbe, degradirano okolje in izčrpavanje naravnih virov pa je povratno pomembno negativno vplivalo na gospodarstvo in kakovost življenja. Ekosistemsko, trajnostno sonaravna prevetritev temeljev obstoječega temelja svetovnega in slovenskega gospodarstva je glede na trende okoljske globalizacije nujna, civilizacijsko pomembna naloga. Tudi finančna kriza opozarja, da danes prevladujoča globalna neoliberalna gospodarska strategija potrebuje razvojno in okoljsko uravnoteženo alternativo.

\section{SVETOVNO GOSPODARSTVO IN PLANETARNO OKOLJE}

V zadnjih sto letih se je število svetovnega prebivalstva povečalo za skoraj 4-krat, število mestnega prebivalstva pa za 20-krat. V obdobju 1900-2000 se je poraba žit povečala za skoraj 5-krat, komercialne energije za več kot 10-krat, poraba fosilnih goriv pa celo za 15-krat.

Ekosistemski kritiki prevladujočega in tudi okoljsko agresivnega zahodnega modela gospodarskega razvoja opozarjajo na številne kritične značilnosti (Baker 2006):

1. Napredek se razumeva $v$ ozkem pomenu, predvsem kot naraščanje nadvlade nad naravo in rabo okoljskih virov zgolj z vidika koristi za človeško vrsto (instrumentalna vrednost narave).

2. V ospredju je ekonomska rast, model obravnava degradacijo okolja kot »neizbežno« posledico razvoja.

3. Individualna potrošnja se obravnava kot najbolj pomembna sestavina človekovega blagostanja, ki se meri kot količina dohodka, ki omogoča nakupe dobrin in storitev. Razvojni model, zasnovan na individualni potrošnji, namesto na krepitvi socialne kohezije, pelje v smeri naraščajoče neenakosti in nevarnosti ciklične recesije. Namesto na povečevanja skupne kakovosti življenja (npr. javnega izobraževanja, zdravstvene zaščite in varstva okolja) se razvojni model osredotoča na povečanja življenjskega standarda posameznika.

4. Gospodarski model ignorira dejstvo, da socialna stabilnost zahteva zaščito naravnih virov, saj degradacija naravnega okolja povzroča socialne motnje, povečuje ranljivost lokalnih skupnosti (npr. pri oskrbi s hrano) in slabša človekovo zdravje.

5. Tradicionalno razumevanje gospodarskega razvoja ne upošteva, da je razvoj gospodarsko razvitih držav zasnovan tudi na izkoriščanju naravnih virov t.i. Tretjega sveta. To vodi $\mathrm{k}$ ustvarjanju revščine naravnih virov, kulture odvisnosti in uvajanja zahodnega, okoljsko destruktivnega modela, ki negira dolgo tradicijo gospodarjenja z naravnimi viri lokalnih skupnosti.

6. Razvojni model »spregleda« dejstvo, da potrošniški zahodni življenjski stil z obremenjevanjem okolja presega absorpcijske zmogljivosti planetarnega ekosistema. Hkrati pa na planetu ni dovolj naravnih virov (vključno s sladko vodo), da bi vsi prebivalci sveta 
dosegli visoko in trajno potrošnjo. Okoljski kritiki torej podčrtujejo dejstvo, da zahodni gospodarski model ne upošteva omejitev gospodarske rasti, ki izhajajo iz zmogljivosti okolja (zlasti biosfere) in omejenosti količine naravnih virov. Tehnološki napredek lahko poveča večjo učinkovitost rabe virov, okoljskih in prostorskih omejitev pa ne more preseči.

Dnevi svetovne ekonomije, zasnovane na povečani porabi fosilnih goriv, avtomobilizmu, količinsko rastočemu in linearnemu (snovno pretočnemu) gospodarstvu, se po mnenju ekologistov in okoljskih ekonomistov zaključujejo. Gospodarski razvoj in življenjski stil bo moral biti strukturiran na način, da bo v okviru omejitev globalnega in lokalnega okolja. Večkratna okoljska kritika obstoječega gospodarskega modela kaže, da se le-ta brez katastrofičnih okoljskih posledic a) ne more razširi na globalno raven in b) ne more trajno nadaljevati v prihodnost. Razvojni model ima torej zgolj kratkoročno perspektivo na zgolj regionalni ravni, prednost pa daje zgolj eni zemeljski vrsti nad celotno biosfero.

Svetovno gospodarstvo bo moralo iz obdobja omejitev razpoložljivega ustvarjenega kapitala preiti v obdobje, ko je ključna omejitev okoljski kapital. Če se bo svetovno gospodarstvo kot podsistem planetarnega okolja širilo na enak način kot do sedaj, bo v določenem trenutku kot rakasto tkivo uničilo naravne sisteme, ki ga omogočajo. Ekonomski kazalci (rast BDP) sveta kot celote so v zadnjih desetletjih pozitivni, trajanje življenja se povečuje, a planetarni okoljski kazalci (izčrpavanje naravnih virov, kakovost okolja, podnebne spremembe, biotska raznovrstnost) so vse bolj negativni. Ekologisti izhajajo iz stališča, da je sedanji gospodarski sistem zasvojen s količinsko rastjo, zanika posledice v okolju in ne upošteva omejitev oziroma nosilnosti naravnih sistemov. Ekonomist Stern (2006) opozarja na podnebno grožnjo svetovnemu gospodarstvu in predlaga takojšen začetek njegovega okoljsko-energetskega prestrukturiranja.

Geograf Kemp (2004) poudarja, da je v sodobnem, tržno zasnovanem finančnem sistemu vrednost vira določena s ceno, ki jo je pripravljen plačati posameznik ali skupina. Številni naravni viri, ki opravljajo okoljske, ekosistemske storitve, pa niso vključeni v navedeni tip gospodarstva, zato jih družba ignorira ali finančno podcenjuje. Poskus izračuna ekonomske vrednosti svetovnih okoljskih dobrin in storitev sredi 90. let 20. st. je pokazal, da je njihova ovrednotena skupna letna finančna vrednost (33 trilijonov dolarjev) za 1,8-krat presegla takratni globalni bruto družbeni dohodek (Constanza in sod. 1997). V primeru, da bi se odločili ekosistemske storitve vključiti v svetovno gospodarstvo, bi bil globalni sistem cen bistveno drugačen od obstoječega. Cene dejavnosti, ki neposredno ali posredno uporabljajo ali ovirajo ekosistemske storitve, bi bile bistveno višje, bistveno zmanjšati pa bi bilo potrebno obdavčitve dela.

Delovanje naraščajočega svetovnega gospodarstva bo v prihodnje še bistveno bolj odvisno od trajnega delovanja storitev okolja, ohranjanja naravnih virov planeta. Vendar so v številnih primerih že sedaj dosežene oziroma presežene zgornje meje zmogljivosti planeta za oskrbo svetovne ekonomije z dobrinami in ekosistemskimi storitvami. Biofizične omejitve svetovnega gospodarstva se kažejo $\mathrm{v}$ dveh temeljnih oblikah: $\mathrm{v}$ končnosti naravnih virov in v končni, omejeni zmogljivosti okolja za sprejemanje antropogenih obremenitev okolja (Plut 2004; 2005). Tako je svetovni ribolov v primežu prelova, gladine talne vode se znižujejo 
na vseh celinah, pašniki so prekomerno obremenjeni z živino, tropski gozdovi izginjajo, izumrtje ogroža desetino vrst sesalcev in tretjino rib. Koncentracije toplogrednega $\mathrm{CO}_{2}$ so najvišje vsaj v zadnjih 420.000 letih. Hkrati velja podčrtati, da ob naraščanju cen nafte supermarketi in bencinske črpalke vse bolj tekmujejo za iste produkte: zemljišča, ki lahko proizvajajo hrano ali biogoriva (bioetanol, biodizel). 800 milijonov lastnikov avtomobilov je v letu 2005 glede energije za pogon tekmovalo za hrano z 1,2 milijardami prebivalcev, ki so živeli z manj kot dolarjem na dan (Brown 2006, 8). V letu 2004 so v ZDA 12 \% koruze uporabili za proizvodnjo etanola, kar pa bi zadostovalo za kritje vseh potreb po žitu za 100 milijonov prebivalcev. Bitka se tvegano prenaša na ozemlja revnih držav, ki se srečujejo $\mathrm{s}$ pomanjkanjem hrane. Zaradi večjega povpraševanja po biogorivih se povečujejo pritiski na zemljišča tropskega gozda. Dvig cen nafte torej trenutno celo negativno vpliva na biotsko raznovrstnost planeta.

V obdobju 1961-2001 se je globalni ekološki odtis povečal za 2,5-krat, svetovno prebivalstvo pa se je (le) podvojilo. Materialne potrebe od leta 1980 zanesljivo presegajo trajne donose naravnih ekosistemov na lokalni in tudi na globalni ravni. Globalne ekološke sledi za več kot $20 \%$ presegajo zmogljivosti planeta, vsako leto se prepad poveča za najmanj $1 \%$ (Brown 2006, 6). Statistična povezanost med rastjo BDP na prebivalca in ekološkim odtisom držav sveta kaže na visoko pozitivno korelacijo (Vintar Mally 2006). Nadaljevanje dosedanjega načina rasti BDP in modela gospodarskega razvoja na račun sedanjega in še večjega preseganja nosilnih zmogljivosti planeta bo ogrozilo eksistenco prihodnjih generacij in pospešilo podnebne spremembe ter izumiranje živalskih in rastlinskih vrst. V obdobju 2000 2050 naj bi se globalno gospodarstvo povečalo za štirikrat (Sustainable development...2003, 193). Postavlja se vprašanje, ali lahko tako obsežno svetovno gospodarstvo ustvari manj družbenih in okoljskih stresov kot sedanje, bistveno manjše.

Nespremenjeni, visoko entropijski vzorec količinsko rastočega svetovnega gospodarstva na omejenem planetu, z omejenimi okoljskimi viri in zmogljivostjo, je pred okoli tremi desetletji trčil na zgornje planetarne okoljske meje, v prvi polovici 21. st. so nujne ključne, civilizacijske spremembe. Po mnenju Ošlaja (2000) namreč prvič v vsej svoji zgodovini človeštvo razpolaga s tehnično silo in znanjem, s katerima lahko uniči vso naravo, vključujoč tudi samega sebe. Paradoksalno, sodobna civilizacija se mora danes še bolj intenzivno ukvarjati s problemom preživetja, na novo mora opredeliti odnos do narave, okolja in ključno preoblikovati materialno dejavnost.

\section{SONARAVNA ZASNOVA SVETOVNEGA GOSPODARSTVA - PRIMEREN ODGOVOR NA OKOLJSKO GLOBALIZACIJO?}

Sonaravno gospodarstvo sloni na smotrni rabi surovin in energije, obnovljivih virih energije, bistveno bolj raznovrstnem, okolju prijaznejšemu prevozu in reciklaži materialov. Ključ izgradnje globalnega gospodarstva, ki lahko ohranja gospodarski napredek, je ustvarjanje trga, ki prepoznava okoljsko, ekosistemsko resnico, zasnovano tudi na upoštevanju potreb prihodnjih generacij, drugih vrst. Trajnostna paradigma poudarja, da je prihodnji ekonomski razvoj možen le v primeru, da ne ogroža ključnega bazičnega sistema, ki omogoča življenje na planetu - torej okolja kot najširšega sistema, katerega (zgolj) ena od sestavin je svetovno 
gospodarstvo. Model trajnostno sonaravnega razvojaje torej izziv tradicionalno pojmovanemu modelu razvoja kot enostavne modernizacije in linearnega napredka, družba pa zgolj prehaja $\mathrm{v}$ različne stopnje ekonomske rasti in vse bolj dominira nad naravo (Baker 2006).

Globalna okoljska trajnostnost je torej predpogoj za ekonomsko (gospodarsko) in od nje odvisno socialno trajnostnost, zato je upravičena zahteva po omejitvah izčrpavanja zalog naravnih virov. Dejansko to pomeni, da bo potrebno »žrtvovanje«, torej ohranjanje (»neraba«) nekaterih že denarno ovrednotenih zalog virov (Markandya in sod. 2002, 24).

Tako kot trajnostni sonaravni razvoj trajno ni mogoč brez okoljskih/ekoloških omejitev in drugačne razdelitve bogastva, tako trajno tudi ni možen sedanji način globalizacije $s$ poglabljanjem socialnoekonomskih razlik in večjimi okoljskimi pritiski. Potreben je premik od pretežno antropocentričnega pojmovanja geografskega okolja, ki ni (več) zgolj arena gospodarstva in bivalno okolje človeka, ima tudi ekosistemski, varovalni pomen, njegova kakovost in delovanje je pomembno za trajno ohranjanje eksistenčnih pogojev za človeško in tudi za druge vrste. Dokazana velika trdoživost in prilagodljivost sodobnega kapitalizma (neoliberalne pa tudi keynesijanske inačice) se je torej znašla na globalnem in lokalnem okoljskem polju pred novim, zelo zahtevnim sonaravnim in socialnim izzivom. Chomsky (2005) in Rizman (2005) opozarjata na dejstvo, da trenutna ekonomska globalizacija poglablja neenakosti med bogatim in revnim svetom, vplivne velike korporacije, ki dejansko nadzorujejo velik del svetovnega gospodarstva, pa dajejo dobičku in neomejenemu uveljavljanju naravnega 'svobodnega' trga prednost tako pred ljudmi, pravičnostjo kot pred naravo, okoljem in interesi nacionalnih držav.

Ekonomska rast je torej omejena s hitrostjo obnavljanja naravnih virov in samočiščenja okolja. Okoljski oziroma ekološki ekonomisti obravnavajo okolje kot obsežnejši sistem od gospodarskega sistema (svetovne ekonomije) in opozarjajo, da ima okolje razen gospodarskih tudi nenadomestljive ekosistemske funkcije. Večplastno pojmovani nosilnosti okolja se mora regionalno in globalno trajnostno sonaravno gospodarstvo prilagoditi, zmogljivosti okolja kot oskrbovanje $\mathrm{z}$ viri in absorpcija odpadkov ter emisij so absolutne omejitve gospodarski dejavnosti človeka (Common in Stagl 2005).

Gospodarstvo je okoljsko sprejemljivo le v primeru, če zadovoljuje načela, principe okoljske trajnostnosti (sonaravnosti), zasnovane na ekologiji. Temeljno načelo okoljske trajnostnosti se namreč glasi: planet lahko preživi le v primeru, da je gospodarstvo in tehnološka dejavnost trajno (trajnostno) v okviru zmogljivosti okolja, naravnih virov. Planetarni ekosistem je sicer dinamičen, prilagodljiv, a hkrati kompleksen in pogosto zelo ranljiv. S posegi lahko človek poškoduje ključne mehanizme ravnovesja in povzroči nepovratne okoljske poškodbe. Sonaravno gospodarstvo (sonaravni razvoj) pomeni, da npr. ribolov ne sme preseči letnega prirastka rib, količina načrpane talne vode količine obnavljanja, erozija prsti stopnje njenega obnavljanja, poseki lesa stopnjo prirastka, emisije toplogrednih plinov zmogljivosti njihovega sprejemanja, predelave in nevtralizacije. Sonaravno svetovno gospodarstvo ne sme uničevati rastlinskih in živalskih vrst hitreje kot poteka zemeljska biološka evolucija. Okolju prilagojeno gospodarstvo ključno označuje (Brown 2006):

1. minimizacija antropogenih snovno-energetskih tokov;

2. obnovljivi viri energije: sončna energija, veter, hidroenergija, geotermalna energija in biogoriva; 
3. namesto prevladujoče rabe avtomobila raznovrsten mozaik učinkovitih načinov prevoza, torej ob okolju bolj prilagojenem avtomobilu še lahko železnico, avtobuse in kolesa;

4. namesto snovno linearnega, pretočnega gospodarstva gospodarstvo, zasnovano na ponovni rabi, reciklaži surovin.

Z vsakim novim strešnim sončnim kolektorjem, reciklažo papirja, vožnjo s kolesom, posajenim drevesom se postopoma približujemo gospodarstvu, ki nam lahko korak za korakom omogoči trajni gospodarski napredek. S potekajočo, večjo rabo obnovljivih virov energije (geotermalne, sončne, vetrne) se spreminja temeljni trend globalizacije, prihaja namreč do rasti lokalizacije gospodarstva svetovne energije (Brown 2006, 8). Ob naraščanju cen nafte in s tem tudi prevoznih stroškov lahko pričakujemo podobne trende v smeri lokalizacije oskrbe s hrano, torej večjo stopnjo lokalne in regionalne samooskrbe.

Dolgoročno je torej zgolj sonaravni, okolju in prostoru prilagojen prometni sistem sposoben omogočiti zadovoljevanje prevoznih, potovalnih potreb sedanje generacije brez ogrožanja eksistenčnih pogojev prihodnjih generacij in biosfere. 21. st. pa naj bi po mnenju Browna (2006) zaznamoval radikalen odmik od avtomobila in cestnega prometa s pomočjo preoblikovanja sosesk, osrednje vloge javnega prometa in tirnega prevoza, večje vloge kolesarjenja ter peš hoje. Temeljni cilj trajnostnih, sonaravnih prometnih sistemov je zadovoljevanje potreb prebivalcev po dostopu in prevozu brez ogrožanja javnega zdravja ali ekosistemov. V primeru, da se človeštvo ne bo odločilo za globalno akcijo zmanjševanja emisij toplogrednih plinov in hkratnega prilagajanja na podnebne spremembe, naj bi naraščajoči stroški podnebnih sprememb znašali celo do 5-20 \% svetovnega BDP na leto (Stern 2006). Kajfež Bogatajeva (2006) pa upravičeno opozarja, da je globalna potrošniška ekonomija tudi v Evropi izrinila v kot načelne principe politike dolgoročnega zmanjševanja realnih vzrokov podnebnih sprememb.

Različni pristopi k udejanjanju koncepta trajnostnosti/sonaravnosti so kazalec različnega vrednotenja pomena narave, okolja, od antropocentričnega do ekocentričnega (biocentričnega). Skrajni antropocentrični pogled na naravo, okolje pojmuje bogastvo narave zgolj z vidika prispevka $\mathrm{k}$ oskrbi človeštva $\mathrm{z}$ dobrinami in storitvami. Na drugi strani pa skrajni ekocentrični vidik vrednotenja narave poudarja njeno vrednost samo po sebi. Navedeni različni vidiki vrednotenja narave, okolja so pomembni za oblikovanje in udejanjanje različnih okoljskih politik (Baker 2006). Ekocentrično zasnovane okoljske politike so usmerjene na raven skupnosti in poudarjajo pomen majhnih, lokalno zasnovanih tehnologij. V ospredju je želja po ohranjanju družbenega blagostanja. Antropocentrični pristop k okoljski politiki pa izhaja iz optimizma glede manipulacije $\mathrm{z}$ naravo in njenimi viri za zagotavljanje koristi človeštvu. Ekonomske vrednote dejansko določajo človeške vrednote, kategorija 'imeti' prevladuje nad kategorijo 'biti' (Fromm 2008).

Glede na postopnost udejanjanja koncepta trajnostnosti/sonaravnosti so po mnenju Bakerjeve (2006) štirje ključni pristopi oziroma razvojni modeli, ki odražajo različen obseg prisotnosti antropocentričnega ali ekocentričnega vrednostnega sistema: kontrola onesnaževanja, šibka sonaravnost, močna sonaravnost in sonaravno idealen model razvoja (preglednica 1). Kontrola onesnaževanja predstavlja absolutno prevlado antropocentrizma, idealni okoljski razvojni model pa absolutno prevlado ekocentričnega vrednostnega sistema. 
Večina držav se nahaja v obdobju udejanjanja kontrole onesnaževanja, le nekatere bogatejše in okoljsko bolj osveščene države so v uvajalni fazi modela šibke sonaravnosti.

Preglednica 1: Modeli trajnostno sonaravnega razvoja

Table 1: The models of sustainable development

\begin{tabular}{|c|c|c|c|}
\hline Razvojni model & Tip razvoja & Prostorska raven & Politika udejanjanja \\
\hline $\begin{array}{l}\text { Idealni } \\
\text { (ekocentrični) } \\
\text { model }\end{array}$ & $\begin{array}{l}\text { - narava kot vrednost sama } \\
\text { po sebi } \\
\text { - biofizikalno uravnotežen } \\
\text { razvoj } \\
\text { - naravnih virov ni mogoče } \\
\text { nadomestiti } \\
\text { - zadovoljevanje potreb, ne pa } \\
\text { želja }\end{array}$ & $\begin{array}{l}\text { - bioregionalizem } \\
\text { - razširjena lokalna } \\
\text { samozadostnost }\end{array}$ & $\begin{array}{l}\text { - pristop od zgoraj } \\
\text { navzdol, decentralizacija } \\
\text { inštitucij } \\
\text { - prioriteta okoljski } \\
\text { politiki } \\
\text { - ekološka modernizacija } \\
\text { proizvodnje, zelene } \\
\text { tehnologije }\end{array}$ \\
\hline $\begin{array}{l}\text { Močna } \\
\text { sonaravnost }\end{array}$ & $\begin{array}{l}\text { - ohranjanje kritičnega narav- } \\
\text { nega kapitala in biodiverzitete } \\
\text { - kvalitativni razvoj in princip } \\
\text { previdnosti } \\
\text { - prehod od rasti k nematerial- } \\
\text { nim vidikom razvoja } \\
\text { - nujnost razvoja Tretjega sveta }\end{array}$ & $\begin{array}{l}\text { - okrepljena lokalna } \\
\text { ekonomija in samo- } \\
\text { zadostnost v okviru } \\
\text { globalnega trga } \\
\text { - zelena in pravična } \\
\text { trgovina }\end{array}$ & $\begin{array}{l}\text { - demokratično } \\
\text { sodelovanje javnosti, } \\
\text { odprtost do alternativ } \\
\text { - integracija okoljskih } \\
\text { načel v sektorske politike } \\
\text { - ozelenjeni izračuni } \\
\text { stroškov in koristi }\end{array}$ \\
\hline $\begin{array}{l}\text { Šibka } \\
\text { sonaravnost }\end{array}$ & $\begin{array}{l}\text { - zamenjevanje naravnega } \\
\text { kapitala z ustvarjenim } \\
\text { - reciklaža } \\
\text { - celoten življenjski krog } \\
\text { produkta }\end{array}$ & $\begin{array}{l}\text { - skromne iniciative } \\
\text { k lokalni ekonomiji, } \\
\text { prevlada globalnega } \\
\text { trga }\end{array}$ & $\begin{array}{l}\text { - pristop od zgoraj navzdol } \\
\text { - pristop k reševanju } \\
\text { onesnaževanja tudi na } \\
\text { izvoru } \\
\text { - mešane kapitalsko- } \\
\text { delovno intenzivne } \\
\text { tehnologije }\end{array}$ \\
\hline $\begin{array}{l}\text { Kontrola } \\
\text { onesnaževanja }\end{array}$ & $\begin{array}{l}\text { - narava kot uporabna vrednost } \\
\text { - izkoriščanje naravnih virov } \\
\text { - eksponenčna, tržno vodena } \\
\text { rast }\end{array}$ & $\begin{array}{l}\text { - globalizacija } \\
\text { - prenos produkcije } \\
\text { k zakonsko manj re- } \\
\text { guliranim lokacijam }\end{array}$ & $\begin{array}{l}\text { - princip na 'koncu pipe' } \\
\text { - kapitalsko intenzivne } \\
\text { tehnologije }\end{array}$ \\
\hline
\end{tabular}

Vir: Baker 2006.

Tako kot trajnostni sonaravni razvoj trajno ni mogoč brez upoštevanja okoljskih/ekoloških omejitev in drugačne razdelitve bogastva, tako trajno tudi ni možen sedanji način globalizacije s poglabljanjem socialnoekonomskih razlik in večjimi okoljskimi pritiski. Potreben je premik od pretežno antropocentričnega pojmovanja geografskega okolja, ki ni (več) zgolj arena gospodarstva in bivalno okolje človeka, ima tudi ekosistemski, varovalni pomen, njegova kakovost in delovanje je pomembno za trajno ohranjanje eksistenčnih pogojev za človeško in tudi za druge vrste. Dokazana velika trdoživost in prilagodljivost sodobnega kapitalizma (neoliberalne pa tudi keynesijanske inačice) se je torej znašla na spolzkem globalnem in lokalnem okoljskem polju, pred novim, zelo zahtevnim sonaravnim izzivom. 
Okoljsko zasnovan razvoj pa ne predpostavlja le zavračanja dominantnega razvojnega modela, temveč tudi drugačno definicijo razvoja. Ključna elementa nove definicije razvoja morata vključiti kvaliteto namesto kvantitete in kulturološko sodelovanje prebivalcev ter njihovih skupnosti. To pomeni, da morajo same skupnosti, ob aktivnem sodelovanju njihovih prebivalcev, od države in trga prevzeti kontrolo razvojnega procesa. Globalno širjenje proste trgovine in eksponenčna rast hegemonije kapitala streže ideologiji rasti in ekspanziji, kar zahteva kritično analizo bazičnih postulatov 'razvoja'. Drastično je potrebno torej opozoriti na paradoks obstoječega gospodarskega modela 'rasti ali smrti' v obdobju izčrpavanja virov okolja in pretečega slabšanja kakovosti okolja ter podnebnih sprememb. Temeljni izziv za gradnjo nove ekonomije je naslednji (Brown 2006, 15): trg mora prepoznati t.i. okoljsko resnico. Sedanje globalno gospodarstvo v cene dobrin ne vključuje okoljskih stroškov. Pesimistična in radikalna protiglobalistična razmišljanja pa močno dvomijo glede predpostavke, da je tržno gospodarstvo kot tako sploh sposobno prepoznati okoljsko resnico, vendar celovite alternative še ne ponujajo.

\section{SLOVENIJA V TESNEM PRIMEŽU OKOLJSKE IN EKONOMSKE GLOBALIZACIJE}

Slovenija je kot delček svetovnega ekosistema in svetovnega gospodarstva pod trajnim vplivom posledic posegov človeštva $\mathrm{v}$ naravno okolje in globalnih ekonomskih trendov. Okoljska globalizacija je tudi za Slovenijo v ospredje postavila načelo planetarne in medgeneracijske okoljske odgovornosti, torej trajno globalno sprejemljivost obsega porabe naravnih virov in obremenjevanja na prebivalca. Slovenijo označuje stabilizacija prebivalstva in prebivalstvenih pritiskov na okolje, a prekomerna poraba naravnih virov in ustvarjanje različnih oblik obremenjevanja okolja ter prostora. Glede na velikost ozemlja in število prebivalcev prispeva relativno velik, planetarno nadpovprečen delež. Zaradi velike odvisnosti od uvožene surovinske in energetske podlage, globalnega onesnaževanja in podnebnih sprememb mora postati aktivnejši soudeleženec svetovnih okoljskih, razvojnih in drugih procesov. Članstvo v okoljsko osveščeni EU prinaša Sloveniji potrebo in obvezo sistematičnega vključevanja okoljskih načel v gospodarstvo in način organizacije vsakdanjega življenja. Tudi ozemeljsko in prebivalstveno majhna Slovenija kot organski del planetarnega ekosistema in svetovne skupnosti se nahaja pred večplastno, zelo težavno nalogo. Kot gospodarsko razvitejša država sveta (okoli 30 . mesta), ki na prebivalca potroši prevelike količine naravnih virov in zato proizvaja globalno prekomerne količine emisij, odpadne vode in odpadkov, je prihodnjim generacijam moralno dolžna zagotoviti možnost preživetja in napredka.

Kljub določenim pozitivnim premikom pri zmanjševanju nekaterih pritiskov na okolje in izboljšanju kakovosti nekaterih sestavin okolja (npr. zraka) so z vidika planetarnih pritiskov na okolje na prebivalca podatki za Slovenijo neugodni in z vidika koncepta planetarne pravičnosti in ocene nosilnosti planeta bistveno previsoki. V letu 2050 bi bili namreč planetarni pritiski svetovnega prebivalstva ob ravni pritiskov na okolje prebivalca Slovenije leta 1997 za 2,54-krat večji. Po metodologiji ekoloških odtisov glede na zmogljivost biološko produktivnih 
zemljišč planeta Slovenija dvakratno presega planetarno sprejemljivo porabo naravnih virov in emisij $\mathrm{CO}_{2}$, po metodologiji okoljskega prostora pa za faktor 3-4. Ekstremna suša poleti 2003 je eden od verjetnih znakov podnebnih sprememb, ki kažejo tudi npr. na dodatne omejitve rabe vode sicer v povprečju vodno bogate Slovenije.

Po porabi naravnih virov in proizvodnji emisij na prebivalca v Sloveniji (podobno kot druge gospodarsko razvite evropske države) torej nekajkrat presegamo za vse prebivalce sveta planetarno, trajno sprejemljivo raven. Poročilo o razvoju (2006) ugotavlja, je bilo v zadnjem obdobju pri trajnostnem razvoju z vidika okolja sicer opazno izboljšanje integracije okoljskih ciljev v gospodarski razvoj Slovenije, ključni slabosti pa sta velika energetska intenzivnost in hitro povečevanje cestnega prometa.

Slovenijo torej še označujejo večja ohranjenost okoljskega kapitala, velika pokrajinska in biotska raznovrstnost, praviloma ozemeljsko ožja (lokalno in delno mikroregionalno) območja čezmernih pritiskov na okolje in onesnaženih sestavin okolja, hkrati pa tudi planetarno dolgoročno nesprejemljiva količina porabe naravnih virov in obremenjevanje okolja na prebivalca (Plut, Špes in Brečko 2002; Plut 2004). Slovenija na splošno še povečuje okoljske pritiske, gospodarski razvoj poteka delno tudi na račun izčrpavanja okoljskega kapitala.

Čeprav je Slovenija po osamosvojitvi nekatere okoljske pritiske zmanjšala, je trenutno še zelo daleč od uresničitve kjotskega cilja o $8 \%$-em zmanjšanju emisij toplogrednih plinov do leta 2012 glede na izhodiščno leto 1986. Podatki Agencije za okolje namreč opozarjajo, da se v obdobju 1986-2004 izpusti toplogrednih plinov niso zmanjšali, predvsem po letu 1999 pa so se pomembno povečali (Kazalci okolja 2006). V obdobju 1986-2004 so se prometne emisije podvojile, zlasti zaradi skokovitega naraščanja emisij osebnih vozil. Torej za stanje okolja ni odgovorna le država, k okoljskim pritiskom sicer različno prispeva vsak od nas, okoljski pritiski in stanje okolja so tudi naše osebno ogledalo.

V strateških razvojnih dokumentih sta med ključnimi strateškimi prednostnimi nalogami navedena trajnostno sonaraven in okoljsko komplementaren policentrični, skladnejši razvoj. S predvidenim, prednostno zasnovanim doseganjem pričakovane visoke gospodarske rasti in hkratnim udejanjanjem nekaterih ključnih, okoljsko spornih razvojnih projektov pa se bodo do leta 2020 povečali izčrpavanje okolja in številni okoljski pritiski (Plut 2008).

Strateški dokumenti namreč izhajajo iz ključne razvojne predpostavke ('razvojnega izhodišča'), da je poglavitni razvojni zaostanek Slovenije za povprečjem razširjene EU še vedno prav na področju gospodarske razvitosti, zlasti na okoljskem področju pa so zaostanki manjši in omejeni na posamezne segmente. Ključni obravnavani strateški razvojni dokumenti Slovenije so zasnovani tako, da so na prvem mestu gospodarsko-socialne razmere, zato napovedujejo večjo materialno blaginjo, zvišanje BDP-ja, večjo gospodarsko rast ter povečanje dodane vrednosti in zaposlenosti. Dvig materialnega blagostanja, povečanje t.i. ustvarjenega kapitala naj bi spremljalo zmanjšanje okoljskega kapitala, kar označuje paradigmo zelo šibke trajnostnosti/sonaravnosti. Nahajamo se torej še vedno v razvojnem modelu kontrole onesnaževanja, torej v uvodni fazi okolju bolj prilagojenega gospodarskega in regionalnega razvoja.

Posebej želimo opozoriti na to, da so bile pri snovanju izbora nacionalnih projektov povsem spregledane pričakovane posledice podnebnih sprememb in nujnost regionalno 
različnega prilagajanja razvojnih usmeritev nanje. Slovenija bo brez dvoma v številnih regijah občutila številne negativne posledice podnebnih sprememb, zato se mora nanje pravočasno pripraviti (Kajfež Bogataj 2001; 2006). Nov projekt prilagajanja gospodarstva, poselitve, načina življenja $\mathrm{v}$ spremenjenih podnebnih razmerah bi moral biti pomemben državni razvojni projekt. Alternativni razvojni program skupine nevladnih organizacij in posameznih strokovnjakov za trajnostni razvoj predlaga za Slovenijo poleg horizontalnih ukrepov (npr. zeleno davčno reformo, sonaravni policentrični razvoj Slovenije) še več skupin projektov (Plan B za Slovenijo 2007), in sicer: prehod na družbo z nizkimi izpusti toplogrednih plinov (trajnostna energetska politika, trajnostna prometna politika), prilagajanje na podnebne spremembe in podeželje kot konkurenčna prednost Slovenije. Med okoljsko ključnimi izhodišči sta poleg povečanja sonaravne rabe obnovljivih naravnih virov tudi ničelna rast porabe energije in občutno zmanjšanje ekološkega odtisa na osebo do leta 2020. Zaradi velikega deleža ozemlja bi bil zelo potreben še razvojni projekt sonaravnega gospodarjenja na varovanih območjih Slovenije.

Za udejanjanje globalno in lokalno zasnovanega trajnostnega sonaravnega razvoja mora Slovenija razen stabilizacije porabe energije povečati rabo svojih obnovljivih virov (vključno $z$ rabo vetrne in vodne energije, pa tudi biomase, sončne in geotermalne energije), vendar na lokacijah, ki so ne samo kar najbolj donosne, temveč tudi okoljsko in socialno optimalne ter lokalno družbeno sprejemljive. Sicer pa so bili v Sloveniji z bogatim domačim znanjem že izvedeni številni uspešni, mednarodno inovativni ekoremediacijski projekti. Ekoremediacije kot uporaba naravnih procesov za obnovo in zaščito okolja so glede na razpršen vzorec poselitve, vodnoekološke razmere in obsežna zavarovana območja v Sloveniji eden od ključnih razvojno-ekoloških projektov. Gre torej za ekoinovacije, ki zaradi pozitivnih učinkov zahtevajo otipljivo državno podporo (Vrhovšek in Vovk Korže 2007).

Predlagamo torej, da bi po izvedeni strokovni sonaravni presoji preoblikovali in dopolnili nabor državnih razvojnih projektov, ki jih je predlagala vlada. Sodimo namreč, da bo ob morebitni možni in pričakovani dopolnitvi ter nekaterih lokacijskih spremembah razvojnih projektov (ob drugih potrebnih ukrepih) regionalni razvoj skladnejši, da bo bolj prilagojen zmogljivostim okolja ter sonaravni rabi v Sloveniji zelo mozaičnega okoljskega kapitala, zlasti glede obnovljivih naravnih virov. Pogrešamo sonaravne razvojne projekte, ki bi omogočili večje razvojno-varovalno aktiviranje endogenih, zlasti naravnih (okoljskih) virov.

Strateški razvojni dokumenti Slovenije se v tipologiji štirih modelov trajnostnega razvoja (Lukšič in Bahor 2006) uvrščajo v model šibke trajnosti, pri katerem trg le delno upošteva okoljsko politiko. Ključni namen je integriranje gospodarske rasti s skrbjo za okolje 'na koncu pipe', zmanjševanje porabe naravnih virov pa ni predvideno. Vsekakor želimo opozoriti, da globalna in regionalna razsežnost posledic okoljskih pritiskov opozarja na vse večjo dolgoročno razvojno in eksistenčno tveganost ključne predpostavke strateških razvojnih dokumentov Slovenije (in drugih državnih strategij, tudi Lizbonske strategije na ravni EU). Izhajajo iz napačne predpostavke, da je z učinkovitimi, dodatnimi kurativnimi okoljskimi ukrepi še mogoče najti okoljski manevrski prostor npr. za nadaljnje povečanje snovno-energetskih tokov za prednostno postavljeno (količinsko) gospodarsko rast.

Globalizirano slovensko gospodarstvo čaka do leta 2020 s strateškega vidika na okoljskorazvojnem polju zlasti: 
1. temeljita energetsko-okoljska prevetritev, zasnovana na prilagajanju na podnebne spremembe in zmanjševanju emisij toplogrednih plinov, in ključni trendi v smeri nizko entropijske in nizko ogljične družbe: $20 \%$-no zmanjšanje izpustov toplogrednih plinov, $20 \%$-no povečanje energetske učinkovitosti in povečanje rabe obnovljivih virov na $20 \%$ končne rabe energije;

2. pospešeno prepoznavanje in vključevanje vseh okoljsko-podnebnih zunanjih stroškov v cene proizvodov in storitev, kar bo med drugim bistveno spremenilo razmerja cen virov energije in ekosistemskega pomena bioproduktivnih zemljišč;

3. večji prispevek slovenskega gospodarstva pri iskanju trajnostno optimalnih sodobnih izzivov širše pojmovane nacionalne varnosti, katere pomembne sestavine so vodna in prehranska varnost (težnja $\mathrm{k}$ samooskrbi, ohranjanje že strateško kritičnega razmerja med kmetijskimi, gozdnimi in pozidanimi površinami!), povečanje energetske varnosti (stabilizacija in nato zmanjševanje porabe energije, večja, a naravovarstveno pretehtana raba domačih obnovljivih virov energije, ohranjanje ekosistemskih storitev, pokrajinske in biotske raznovrstnosti ter tudi okoljsko uravnotežen, skladnejši regionalni razvoj celotnega poseljenega ozemlja Slovenije.

Ali to hočemo in zmoremo? Najprej udejanimo spoznanje, da je razvoj več kot gospodarska rast. Trende lahko hitro spremenimo, če je to volja večine ljudi, prenesena v sfero politike in gospodarstva, ki mora to voljo udejaniti.

\section{SKLEP}

Pojav prostorskih in biofizičnih meja za ekonomsko rast je torej redefiniral ključne pogoje za ustvarjanje bogastva v 21. st. Po mnenju številnih ekonomistov je prav dejstvo, da okolje, številni viri okolja (skupna dobrina) v obstoječem ekonomskem sistemu nimajo tržne cene, temeljni razlog za degradacijo okolja in neupoštevanje biofizičnih meja pri rabi naravnih virov.

Po mnenju Seitza (2008) ni nobenega dvoma o potrebi pospešene gospodarske rasti držav v razvoju, vendar brez ponavljanja bolečih degradacij okolja, ki so označevale dvig materialnega blagostanja razvitih držav ter nujnosti čimprejšnje stabilizacije prebivalstva in zmanjševanja socialnih razlik. Postavlja pa vprašanje, ali je realna potreba povečevanja količinske gospodarske rasti v gospodarsko razvitih državah, kjer je dosežena okoljsko želena stabilizacija prebivalstva. Zavedati pa se moramo trenutno velike nepriljubljenosti predpostavke, da bi udejanjanje želje po vedno večjem posedovanju materialnih dobrin v bogatih državah povzročila obsežno preobremenitev planeta (Seitz 2008, 240).

Zaradi povečevanja svetovnega prebivalstva in porabe naravnih virov na prebivalca je onesnaženost okolja konec 20. st. postala planetarno razširjena. V posameznih primerih materialna dejavnost človeštva presega globalno nosilnost okolja, želen dvig materialnega blagostanja spremlja izčrpavanje virov okolja in slabšanje kakovosti okolja. Geografski prostor je dobil novo, ekosistemsko dimenzijo, katero tudi gospodarstvo ne sme spregledati. Večplastno pojmovani nosilnosti planeta se mora svetovno gospodarstvo, kot ena od sestavin globalnega okolja, prilagoditi. Narašča spoznanje, da se izčrpavanju in degradaciji 
okolja lahko izognemo zgolj z okolju in naravi prilagojeno dejavnostjo, ki bo ohranila ključne planetarno pomembne vire ter življenjske oskrbne sisteme. Rekonstrukcija gospodarstva pa zahteva spremembe na vseh poljih človekove dejavnosti, načinu organizacije podjetništva in svetovnega gospodarstva ter trgovine, vključno s spremembami v sistemu vrednot. Okoljski gospodarski razvoj po mnenju Bakerjeve (2006) ne pomeni zgolj zaščite narave in okolja, temveč ustvarjanje okoljske družbe, ki bo živela v harmoniji z naravo. To pomeni uskladitev gospodarskega dejavnosti, družbenega napredka in okoljske zaščite, torej povečevanje blagostanja posameznika in človeštva brez destrukcije planetarnega ekosistema.

Promocija in praktično udejanjanje sonaravnega svetovnega gospodarstva dosledno v okviru planetarnih okoljskih zmogljivosti oziroma omejitev predstavlja v tem civilizacijskem trenutku tudi dolgoročno sprejemljivo prenovo osnovnih vidikov obstoječega ekonomskega sistema, dograjevanje trajnostne globalne razvojne paradigme. Nespremenjeni, visoko entropijski vzorec količinsko rastočega svetovnega gospodarstva na omejenem planetu, z omejenimi okoljskimi viri in zmogljivostjo je pred okoli tremi desetletji trčil na zgornje planetarne okoljske meje. V prvi polovici 21. st. so torej nujne ključne spremembe sestave svetovnega gospodarstva, ki bi minimalno povečevalo entropijo planeta. Stališče, da ne obstaja realna alternativa neoliberalnemu gospodarskemu modelu, je v sedanjem okoljskem trenutku ogroženega planeta in tehnološkem trenutku človeštva bolj neverjetna kot kadarkoli prej! Chesney (2005) sodi, da je nujna humana postkapitalistična ureditev, saj je vsak napredek v zgodovini moral na določeni točki premagati predstavo, da je nemogoč, ker tega prej še niso uresničili.

Strateški razvojni dokumenti Slovenije se po namenu, ciljih in opredelitvah uvrščajo v strateške razvojne modele, ki jih označuje tržno-socialna zasnova z elementi okoljske trajnosti, ne pa celostna, gospodarsko, socialno in okoljsko uravnotežena, torej ekosocialna tržna zasnova, ki ključno opredeljuje trajnostno zasnovane razvojno-varovalne strateške modele (Plut 2008).

Šibko stopnjo okoljske trajnosti Slovenije (in EU) do leta 2015 je torej treba udejanjiti brez povečanja porabe absolutne količine surovin in primarne energije, to pa je ključna sonaravna strateška naloga. Za višjo stopnjo sonaravnosti, za doseganje trajne organizacije gospodarstva in poselitve v okviru zmogljivosti okolja, pa bo morala tako Slovenija kot EU do sredine 21. st. za dva do trikrat zmanjšati pritiske na globalno okolje. Obdobje do leta 2015 naj bi torej bilo začetno obdobje udejanjanja skrajno zahtevnega trajnostnega sonaravnega prehoda, temeljni okoljski cilj v naslednjih letih pa naj bi bila stabilizacija porabe primarne energije in pritiskov na okolje ter temu prilagojen izbor in udejanjanje nacionalnih razvojnih projektov.

\section{Viri in literatura}

Baker, S. 2006: Sustainable development. Routledge. London, New York.

Brown, L. 2006: Plan B 2.0: Rescuing a planet under stress and a civilization in trouble. Earth Policy Institute. New York.

Chesney, R. 2005: Uvod k Profit pred ljudmi (N. Chomsky). Zbirka Tigr 2, 15-26. Ljubljana. 
Chomsky, N. 2005: Profit pred ljudmi. Sanje, Zbirka Tigr 2. Ljubljana.

Common, M., Stagl, S. 2005: Ecological economics. Cambridge University Press. Cambridge.

Constanza, R. in sod. 1997: The value of the world's ecosystem services and natural capital. Nature 387, 15, 253-259. London.

Fromm, E. 2005: Umetnost ljubezni in življenja. Mladinska knjiga. Ljubljana.

Kajfež Bogataj, L. 2001: Klimatske spremembe in njihove posledice. Gozdarski vestnik 59, 4, 203-208. Ljubljana.

Kajfež Bogataj, L. 2006: Podnebne spremembe in prihodnost Slovenije. V: Pogovori o prihodnosti Slovenije - izzivi podnebnih sprememb. Urad Predsednika Republike Slovenije, 62-69. Ljubljana.

Kazalci okolja 2005. Agencija RS za okolje. Ljubljana 2006.

Lukšič, A., Bahor, M. 2006: Trajnostni razvoj v luči Lizbonske strategije in njene revizije. V: Slovenija v evropski luči znanja in razvoja, 39-53. Fakulteta za družbene vede. Ljubljana.

Markandya, A., Harou, P., Bellu, L., Cistulli, V. 2002: Environmental economics for sustainable growth. Cheltenham.

Ošlaj, B. 2000: Človek in narava. Osnove diaforične etike narave. Znanstveno in publicistično središče. Ljubljana.

Plan B za Slovenijo. Umanotera. Ljubljana 2007.

Plut, D. 2004: Zeleni planet? Prebivalstvo, energija in okolje v 21. stoletju. Didakta. Radovljica.

Plut, D. 2005: Teoretična in vsebinska zasnova trajnostno sonaravnega napredka. Dela 23, 59-114. Ljubljana.

Plut, D. 2008: Slovenia 2020 - Development at the expense of the environment? Five minutes of democracy. The Liberal Academy, 333-352. Ljubljana.

Plut, D., Špes, M., Brečko, V. 2002: Slovenia - Country Studies - Northern Group. V: Environmental problems of East Central Europe. Routledge studies of societies in transition 16, 228-247. London, New York.

Poročilo o razvoju 2006. Urad za makroekonomske analize in razvoj. Ljubljana 2006.

Rizman, R. 2005: Uvodni zapis k slovenski izdaji Profit pred ljudmi (N. Chomsky). Zbirka Tigr, 6-14. Ljubljana.

Seitz, J. 2008: Global issues: an introduction. Blackwell. Malden.

Stern, N. 2006: The economics of climate change - Stern Review. The British Government. London.

Sustainable development in a dynamic world. The World Bank. Washington 2003.

Vintar Mally, K. 2006: Okoljevarstvena in socialnoekonomska protislovja držav v razvoju. Doktorska disertacija, Oddelek za geografijo, Filozofska fakulteta. Ljubljana.

Vrhovšek, D., Vovk Korže A. 2007: Ekoremediacije. Filozofska fakulteta Univerze v Mariboru, Mednarodni center za ekoremediacije, Limnos. Maribor. 


\section{ENVIRONMENTAL GLOBALIZATION, WORLD ECONOMY AND SLOVENIA}

\section{Summary}

A historic comparison of the relationship between the environment and the economy in most cases fails to show harmony. This is especially true for the period after the industrial revolution. Linear economic development, planned on the presumption of a possibility of permanent economic growth and profit increase, has been causing environmental damages throughout the history of mankind. A degraded environment and the exploiting of natural sources had a significant recurrent negative impact on the economy and the quality of life. The phenomenon of environmental and biophysical barriers for economic growth has therefore redefined the key conditions for creating wealth in the $21^{\text {st }}$ century.

Socialism failed since it did not recognize economic truths and human rights while capitalism can fail since it will not be capable of identifying the environmental truth in time. In Seitz's opinion (2008) there is undoubtedly a need for accelerated economic growth in developing countries, yet without repeating painful environment degradation that denotes the rise of material well-being in developed countries. However, he asks whether there is a real need for increasing economic growth in economically developed countries, where environmental stability of inhabitants has been achieved. He is aware of the major unpopularity of a supposition that realizing the desire for bigger and bigger possession of material goods in wealthy countries could cause an extensive overburdening of our planet.

Due to the considerable growth of world population and the consumption of natural resources per inhabitant, pollution at the end of $20^{\text {th }}$ century has expanded globally. In many separate examples, the material activity of mankind has exceeded the tolerance of global environment.

Geographical space has a new dimension to the ecosystem which the economy should not overlook either. The world economy as one of the components of the global environment should adapt its multi-layered comprehension to global capacity. Insight is increasing into avoiding the exploitation and degradation of environment only with activities adjusted to the environment and nature which preserve the key planetary important resources as well as vital supplying systems. However, reconstruction of the economy demands changes in all fields of human activities, in organizing business and world economy as well as trade, including changes in the value system. Environmental economic development means not only the protection of nature and the environment but also the creation of an environmental society that will live in harmony with nature. It means the adjustment of economic activities, social progress and environment protection, consequently enlarging the well-being of both the individual and mankind without the destruction of planetary ecosystem.

The promotion and practical fulfillment of a sustainable world economy, consistently in the frame of planetary environmental capabilities or limitations at this point of time also presents a long-term acceptable renovation of elementary views of existing economic system, perfecting a sustainable global development paradigm. Unchanged, the highly entropic pattern of raising the world economy on a limited planet, with limited environmental 
sources and capacity, clashed about three decades ago with upper planetary environment boundaries; therefore, key changes to world economic structure in the first half of the $21^{\text {st }}$ century are necessary, which would minimally enlarge the entropy of the planet. The standpoint that a real alternative to a neoliberal economic model does not exist is in the present environmental moment of the endangered planet and in the technological moment of mankind more unbelievable than ever before! Chesney (2005) believes that human postcapitalistic regulation is necessary as every piece of progress in history had to overcome the notion that it was not possible as it had not been achieved previously.

Strategic development documents of Slovenia relating to purpose, goals and definitions classified in strategic development models are denoted by marketing schemes with elements of environmental durability and not holistically, economically, socially and environmentally balanced, thus decisively defining sustainably designed developmental-protective strategic models. The weak degree of environmental sustainability in Slovenia (and in EU) until the year 2015 should therefore be realized without increasing the quantity of consumption of raw material and primary energy; it is the key sustainable strategic duty. To reach a higher level of sustainability and permanent economic organization and population distribution in regard to the environment capacity, Slovenia will have to reduce three times the pressures on global environment by the middle of $21^{\text {st }}$ century. The period from now until 2015 should therefore be the beginning period of realizing this extremely demanding sustainable transition. The basic environmental goal in the coming years should be the stabilization of primary energy usage and pressures on the environment, adjusted selection and the realization of national development projects. 